\title{
Community Participation Arrangements to Prevent Illegal Drilling ${ }^{1}$
}

\author{
Iza Rumesten R.S. ${ }^{*}$, Febrian, Helmanida, Agus Ngadino \\ Faculty Law, Sriwijaya University, Indonesia. \\ *Corresponding author E-mail: rumesten_iza@yahoo.com
}

\author{
ARTICLE INFO \\ Keywords: \\ Environmental Law; Illegal \\ Drilling; Participation \\ How to cite: \\ Rumesten, I.R.S., Febrian., \\ Helmanida., and Ngadino, \\ A. (2018). "Community \\ Participation Arrangements \\ to Prevent Illegal Drilling," \\ Hasanuddin Law Review, \\ 4(3): 348-355 \\ DOI: \\ 10.20956/halrev.v4i3.1291
}

\begin{abstract}
The practice of illegal drilling does not only result in destruction for to the environment, but also result in the social gap, national losses, and people's lives. It happens to illegal drilling conducted manually using traditional equipment and less operational standard. This illegal drilling may happen because ineffective law applied and no regulation on social participation in the Law of oil and natural gas. This research uses the normative method, the result of research is analyzed qualitatively. The research showed that the active social participation was needed in environmental law enforcement to prevent a great number of illegal drilling practice, the higher level of social participation in environmental law enforcement, and the smaller illegal drilling practice could be. Thus, there must be any act arranging for social participation in enforcing the environmental law arranged in the law No. 22 of 2001 because of those the local societies who get the direct effect of environmental destruction as a result of drilling of oil and natural gas illegally.
\end{abstract}

Copyright (C) 2018 HALREV. All rights reserved.

\section{Introduction}

The activity of oil and natural gas drilling closely related to environmental destruction as its side effect. The negative impacts in the exploitation of minerals as a result of the mining business in the form of forest destruction, pollution of the sea, the outbreak of disease, the occurrence of community conflicts in the mining circle, ecological damage and the possibility of floods and landslides. ${ }^{2}$ The same impact can also arise due to illegal

\footnotetext{
1 This paper is the result of competitive research of research institutions and dedication to the society of Sriwijaya University of Fiscal Year 2017 Nomor: 1012/UN9.3.1/PP/2017.

2 Puluhulawa, F.U. (2011). “Pengawasan Sebagai Instrumen Penegakan Hukum pada Penglolaan Usaha Pertambangan Mineral dan Batu Bara”. Jurnal Dinamika Hukum, Vol. 11 No. 2, p. 307.
} 
drilling practices. Accordingly, Riyandani ${ }^{3}$ said illegal drilling is illegal mining, processing, oil from old wells or making wells without permits. The practice of illegal drilling is likely to continue to grow in number again, so the possibility of environmental damage will also increase. The practice of illegal drilling is more possible getting increase in number, that the possibility of living, environmental destruction as the side effect is getting bigger.

The great number of illegal oil drilling result from many factors, such as: Firstly, some neglected oil well of PERTAMINA is taken over by the society illegally; Secondly, there is no socialization from the government on the prohibition on illegal drilling, that the practice of illegal drilling is getting increase conducted by the society. It shows from the statement of Indonesian Executive Director of Resources Studies (known as IRESS), Marwan Batubara, that the practices of illegal drilling in Musi Banyuasin become endemic, and it has happened for years without any action taken. Moreover, these illegal practices are conducted in the group with certain apparatus who protect them. ${ }^{4}$

The results of research in Musi Banyuasin show that the community around the oil and gas, mining areas are not included in environmental law enforcement activities, however, the society would be the first one who gets the direct effect of the environmental destruction from the drilling activity. This consideration became fundamental of the urgency of social participation around the drilling area to prevent environmental destruction as the side effect of illegal drilling practice. In line with the background, the problem formula of the study refers to how the correlation of social participation in upholding environmental law toward illegal drilling practices.

\section{Method}

This legal study uses the normative approach in purpose to evaluate the positive law, in the meaning of collecting, explaining, analyzing, interpreting and examining the positive norms arranging on oil and natural gas drilling. The result of analyzing the normative legal materials, then analyzed using qualitative methods, that an analysis procedure resulting in descriptive-analytic data.

\section{Constitutional Perspectives on Social Participation and Environmental Law Enforcement}

The 1945 Constitution of the Republic Indonesia gives guaranty to sustained of living environment. It shows in the Article $28 \mathrm{H}$ para (1), "Everyone shall be entitled to be prosperous, reside, and obtain proper and sound environment and medical services". Meaning that the government has arranged in such way that the right to get good and healthy environment become right of any citizen, thus any activity conducted by the government in line with development (including exploration and exploitation of my material) must take care of fulfilling the citizen's right to get good and healthy living environment. Then, further confirmed in the Article 33 para. (4) that the national economy shall be held based on economic democracy with the principles of togetherness, efficiency with

3 Lioty, R.R. (2017). “Penanganan Illegal Tapping, Illegal Drilling dan Penyelewengan Bahan Bakar Minyak (BBM) Bersubsidi di Indonesia Tahun 2011-2015". Jurnal of International Relations, Vol. 3 No. 4, p. 96.

4 Source: $\quad$ http://sumsel.tribunnews.com/2017/01/25/bereskan-illegal-drilling-menkopolhukham-perlu-panggilkapolri-dan-panglima-tni. Accessed on April 19, 2017. 
justice, sustainability, environmental perception, independence, and by keeping the balance of the national economic progress and unity.

As result, the follow-up action conducted by the government to give a good and healthy environment to all citizens and to do development with environmental bases is issuing the Law No. 32 of 2009 on the Protection and Maintain the Living Environment. It shows in regulation considering letter b of the Law No. 32 of 2009 arranging that the national economic development as being mandated by the 1945 Constitution.

The practice of ignoring the ex-mining areas that no more used to conduct by PERTAMINA a private company, become the main cause of getting increase the illegal drilling practices done by the society. It is a gates Article $28 \mathrm{H}$ para. (1) and Article 33 para. (4) of the 1945 Constitution as well as the Law No. 32 of 2009. They strictly arrange that any economic activity conducted must be based on environment. Ignoring exmining areas proves that the drilling activity has no environmental principle and mature planning. In this case, Priyanta states that the developmental implementation in line with environmental and space arrangement so far tending to unplanned and not sustained have given an effect of decreasing the quality and function the environment including the natural resources in it. ${ }^{5}$ The decreasing of living environment and natural resources results from the less human consciousness of sustainability persistence of living environment. ${ }^{6}$ Hence, continuous development based on the living environment can be formulated as a conscious and planned effort covering the environment, including its resources into the development process granting the ability, welfare and living quality of present and future generation. ${ }^{7}$

The direct consequence of continuous development is any natural resources usage and production must be in accordance, harmony, and balance with the living environmental function. In line with the fact, as its consequence, any policy, plan, and/or program of development must be based on the responsibility to do the living, environmental conservation and achieve the goal of continuous development, decentralization, and confession and reward to local and environmental wisdom. ${ }^{8}$ Moreover, the state authority toward mining of the greatness of people welfare results in state responsibility that any form of benefiting the mining natural resources and its result (natural richness), must develop the society prosperous and welfare into reality. The country should guarantee any people right in and on the earth that can be produced or consume directly by the society. ${ }^{9}$ In other words, the country has a responsibility to prevent any actions of any party resulting in the society lost their rights obtained in and on the earth, including the right to get healthy environment.

5 Priyanta, M. (2015). "Pembaharuan dan Harmonisasi Peraturan Perundang-Undangan Bidang Lingkungan dan Penataan Ruang Menuju Pembangunan Berkelanjutan". Hasanuddin Law Review, Vol 1, Issue 3. p. 341.

6 Subyakto, K. (2015). "Azas Ultimum Remidium Ataukah Azas Primum Remidium yang Dianut dalam Penegakan Hukum Pidana pada Tindak Pidana Lingkungan Hidup pada UU No. 32 Tahun 2009 tentang Perlindungan dan Pengelolaan Lingkungan Hidup". Jurnal Pembaharuan Hukum, Vol II, No. 2 MeiAgustus. p. 210.

7 Mina, R. (2016). “Desentralisasi Perlindungan dan Pengelolaan Lingkungan Hidup Sebagai Alternatif Menyelesaiakan Permasalahan Lingkungan Hidup". Jurnal Arena Hukum, Vol. 9 No. 2. p. 154.

8 Widowaty, Y. (2012). “Konsep Sustainable Develompment sebagai Bentuk Perlindungan terhadap Korban Tindak Pidana Lingkungan Hidup". Jurnal Media Hukum, Vol. 19 No. 2. p. 269.

9 Franky Butar-Butar. (2010). "Penegakan Hukum Lingkungan di Bidang Pertambangan”, Jurnal Yuridika, Vol 25 No. 2, Mei-Agustus. p. 189. 
In the same way, the 1945 Constitution also gives legal basic guaranty for social, active participation in the development. It shows in the Article 28C para. (2), arranging that anyone has right to develop himself in struggling his right collectively to develop his society, country, and state. Strictly, it shows in the Article 28D para. (3), arranging that each citizen has right to obtain the same opportunity in the government. In this case, the right to get good and healthy environment is part of human right considered urgent and must be a priority.

\section{Enforcing the Environmental Law and Illegal Drilling Practice in Indonesia}

The oil mining becomes a pulling factor for number of newcomers. It included Army or Police, members of the legislative, and devices village also engaged on illegal drilling oil business. ${ }^{10}$ It makes the business difficult to control. Thus, the mining business results in bigger destroyed effect on the living environment than another commodity business. Bigger environmental damage happens to the beginning activity when the exploitation and exploration process conduct. This environmental damage effect appears in physical damage to the environment such as forest logging, water pollution (river, lake, sea), land pollution, and air pollution, that nature becomes unfriendly with human beings. Moreover, the effect of environmental damage gives influence toward local society on its social-culture, such as the loss of a certain tradition conducted before and after the harvest that used to conduct by the traditional society, the loss of society live had previously depended on the land, forest commodity, and river.

The natural oil becomes strategic un-newest natural resource having a vital role in providing industrial material. The Law No. 32 of 2009 on the Living Environment Maintain provides three kinds of instruments of enforcement, environmental, legal, that are administrative, civic, and criminal law enforcement. For this administration, legal enforcement refers to an effort to prevent the happening of environmental pollution and destruction. Hence, it proposes to punish the actor of environmental pollution and destruction. ${ }^{11}$

It is in line with the idea stated by Rangkuti that environmental law enforcement closely related to the apparatus ability and society, obedience toward applying the regulation, covering three legal fields, administrative, criminal and civil laws. Therefore, the environmental law enforcement becomes an effort to obtain obedience toward regulation and requirement in legal provision applying generally and individually, through supervision and implementation (or punishment) of administrative, criminal and civic instruments. ${ }^{12}$ Administrative instrument can be prevented and purposes to uphold the environmental regulation. The law enforcement may be applied to activities relating to permission requirement, environmental quality standard, environmental management plan, and others. Besides training in the form of instruction and guideline as well as administrative supervision, to an employer in an industrial field should beneficial of concept "pollution prevention pays" be implanted in the process of production. ${ }^{13}$ Moreover, the administrative sanction is purposed especially for interest protection kept by regulation being broken.

10 Sununianti, V.V. (2018). "Labor and Sustainable Development in Traditional Oil Mining", IOP Conference Series: Earth and Environmental Science, Volume 145, conference 1: doi:10.1088/1755-1315/145/1/012105

11 Husin, S. (2014). Penegakan Hukum Lingkungan Indonesia. Jakarta: Sinar Grafika. p. 92.

12 Rangkuti, S.S. Op. Cit., p. 190.

13 Ibid., p. 192. 
The following are several kinds of administrative, legal enforcement instruments:

a) The governmental force or forced action (bestuurs dwang).

b) Forced money (publiekrechtelijke dwangsom).

c) Closing the business workplace (sluiting van een inrichting).

d) Stopping any machinery activity of the compan (buitengebruikstelling van een toestel).

e) Withdrawing permission through the process of reminding government force, closing and force money. ${ }^{14}$

The second law enforcement after administrative ones is civic legal enforcement. It proposes to focus on the effort of compensating lawsuit by victims (society) to the environmental destroyer. This effort becomes legal ones purposing to help the state duty, because of the state no need to spend more cost to uphold the law (law enforcement cost), this cost belongs to society's responsibility.

The criminal law enforcement is always considered as ultimum remidium or the last legal effort because this enforcement conducted to give sentence, punishment (wary) or fine to the act of living, environmental pollution, and destruction. The enforcement of the environmental criminal law has no function to recover the polluted environment as the result of developmental activities (mining), it only gives a wary of the act of environmental destruction.

The mining law has a close relation to environmental law, therefore, any mining activity, whether related to general mining or oil and natural gas drilling, should give responsibility to take care the persistence of living environmental supporting and collecting power. The purpose of implementing business activity on oil and natural gas stated in Act 3 of the law No. 22 of 2001, are to: a) Guaranty implementation and control on oil and natural gas production as the natural and developmental resources, considered strategic and vital; b) Support and grow the national ability to have the more competitive ability; c) Increase the state income and give a great contribution to the national economy, develop and strengthen the Indonesian industry and trading; and d) Create workplace, recovery environment and increase people welfare and prosperity.

Having considered complete, there is no single verse in the Law No. 22 of 2001 on Oil and Natural Gas arranging on enforcing the environmental law for the actor of environmental pollution as a result of mining practice on oil and natural gas. Also, the social participation, there is no single verse in the Law arranging social participation or involves in managing, mining activity on oil and natural gas and social participation in enforcement the environmental law of oil and natural gas drilling activity. However, the local society will be the first one who gets the direct effect of the environmental damage as the result of oil and natural gas drilling activity conducted by the government. Thus, it is urgent to arrange a certain act and verse in the Law No. 22 of 2001 on oil and natural gas related to social participation in enforcing environmental law.

In line with criminal sanction, Article 52 the Law No. 22 of 2001 arrange that anyone conducting exploration and/or exploitation without having cooperation contract as stated in Article 11 para. (1) made in the case using a sentence, punishment maximum 6 (six) years and fine maximum Rp 60.000.000.000,- (six billion rupiah).

14 Erwin, M. (2011). Hukum Lingkungan dalam Sistem Kebijaksanaan Pembangunan Lingkungan Hidup, Bandung: Refika Aditama. p. 117. 
These sanctions only apply to those who conduct exploration and exploitation without having the cooperation contract, not civic sanction and criminal sanction for the actor of pollution as a result of oil and natural gas mining. This act does not apply effectively because the illegal drilling practice, especially in Musi Banyuasin, getting often conducted. It proves by increasing the number of illegal drilling oil wells belong to society. 15

Law enforcement refers to a process to achieve legal wishes into reality. Then, the legal wishes covering, ideas of lawmaker institution formulated in legal regulation. ${ }^{16}$ The formulation of legal maker ideas put into legal rule has contributed to deciding on how the law enforcement implements. In the end, the process of law enforcement gets its peak on the implementation by apparatus of legal upholder himself. From the fact, with extreme intonation, it says that the success or failure of the legal upholder in conducting his duty has begun since the legal regulation being made. According to its subject legal enforcement refers to the effort of certain law enforcement apparatus to guaranty and make sure the implementation of the law and the apparatus may use force power in the law enforcement process. ${ }^{17}$

Law enforcement has to mean on how the law must apply, that in its implementing some elements must take into consideration. ${ }^{18}$ In this case, So Wong Kim believes that there are minimum four dimensions that influencing quality of environmental law enforcement: real environmental regulation, lawbreaker, the victim (society), and apparatus of legal upholder, where the four dimensions give effect each other and take place in one structural space of politic, social, economy, and culture in certain condition. ${ }^{19}$

The expert opinions show the importance of social participation in the development process, especially in keeping the environmental law. In line with the matter, Diana Conyers explains 3 necessary reasons for social participation. First, social participation becomes a useful tool to obtain information about society condition, need, and behavior because without the presence of the society developmental program will fail. Second, society will trust more on the project or program of development if they fail to be involved, from the preparation, planning and implementation processes. It results in a sense of belonging to the developmental project. Third, it supports public participation

15 Source: http://palembang.tribunnews.com/2016/02/17/ada-800-titik-illegal-drilling-tersebar-di-kabupaten-muba. Accessed April 19th 2017. There are 800 points of illegal oil wells in Musi Banyuasin Regency, including Sanga Desa District, in Keban Village and Kemang Village (400 points), Lawang Wetan Sub-district, Talang Pejaring Village (200 point), and Babat Toman Sub-District, Sungai Angit Village (200 points). http://nasional, republika.co.id/berita/nasional/daerah/16/09/21/oduep8396-polda-sumsel-tangani-illegal-drilling-

104-sumur-minyak. Accessed Oktober 14th 2016. Krisman Sihotang said there are 104 oil wells belonging to pertamina that are exploted, 84 wells are located in Mangunjaya and another 20 wells are in Keluang. The majority of oil wells located in Mangunjaya and Keluang is cultivated by Pertamina after 1970, the wells are still being exploited, there are some wells that are managed to stop the management but they are done in order to see the economic aspect, not abandoned

16 Akhmaddhian, S. (2016). "Penegakan Hukum Lingkungan dan Pengaruhnya Terhadap Pertumbuhan Ekonomi di Indonesia (studi Kebakaran hutan Tahun 2015)". Jurnal Unifikasi, Vol 3 No. 1. p. 6.

17 Kartono. (2009). “Penegakan hukum Lingkungan Administratif dalam Undang-Undang Perlindungan dan Pengelolaan Lingkungan Hidup". Jurnal Dinamika Hukum, Vol. 9 No. 3. p. 247-257.

18 Akhmaddhian, S. (2013). "Peran Pemerintah Daerah Dalam Mewujudkan Hutan Konservasi Berdasarkan UU No. 41 Tahun 1999 Tentang Kehutanan (Studi di Kabupaten Kuningan)". Jurnal Dinamika Hukum: Vo. 13 No. 3. p. 13.

19 So Woong Kim. (2013). "Kebijakan Hukum Pidana Dalam Upaya Penegakan Hukum Lingkungan Hidup". Jurnal Dinamika Hukum. Vol. 13 No 3. p. 416. 
in many countries for many ideas appear that it is right of democracy when the society take part in developing the society itself. 20

Involving the society in enforcement the environmental law will really help the government in obtaining information related to the problem of this environmental law in local areas, it also increases social willingness to work together with the government, especially in accepting and conduct the governmental decision and the most important is the society voluntary help to protect and uphold the environmental law in their areas. Thus, it is logical to say that the social presence gives significant effect on the environment and able to give many resolution alternatives for main problems of environmental law enforcement. It can be concluded that the high level of social participation in enforcing the environmental law, the smaller chance of environmental damage.

As a result, the society has a vital role in enforcing the environmental law; they are as developmental agents, as well as play as developmental target, for they not only give a great role in developmental succeed, but also as an urgent actor in the development, they also the one who gets the result and keeper the governmental results. For that reason, the social participation in enforcement the environmental law is urgent that it needs more attention.

\section{Conclusion}

The right to get healthy living environment is a constitutional right. Then, one of its bases applied in managing the living environment as stated in the Law No. 32 of 2009 are participative principle. Consequently, the Law No. 32 of 2009 should be an organic law for any regulation of oil and natural gas that any activity in gas and natural oil production (exploration and exploitation) specially beginning industry must follow the continuity and environmental development principle and based on participative principle. The mining law has closely related to environmental law, any mining business has a responsibility to take care the persistence of living environment. Keeping the living environmental persistence is not only the responsibility of the government as the state implementation, but also the responsibility of all society as the party who get firstly the effect of living environmental destruction. The higher level of social participation in enforcing the environmental law, the smaller chance of environmental damage.

The increasing of illegal drilling practice is the result of no special act arranging the social participation in the law No. 22 of 2001 on Oil and Natural Gas. The society participation in keeping the environmental law greatly helps the government in obtaining the information related to keeping the environmental law in local areas, increase the society's willingness to work together with the government in enforcement the environmental law, and help to protect and keep the environmental law.

20 Conyers, D. (1992). Perencanaan Sosial di Dunia Ketiga, SuatuPengantar, Translated: Susetiawan, Yogyakarta: Gadjah Mada University Press. p. 21-22. 


\section{References}

Akhmaddhian, S. (2013). "Peran Pemerintah Daerah Dalam Mewujudkan Hutan Konservasi Berdasarkan UU No. 41 Tahun 1999 Tentang Kehutanan (Studi di Kabupaten Kuningan)". Jumal Dinamika Hukum, 13 (3): 43-53.

Akhmaddhian, S. (2016). "Penegakan Hukum Lingkungan dan Pengaruhnya Terhadap Pertumbuhan Ekonomi di Indonesia (studi Kebakaran hutan Tahun 2015)". Jurnal Unifikasi, 3 (1): 1-35.

Conyers, D. (1992). Perencanaan Sosial di Dunia Ketiga, SuatuPengantar, Translated: Susetiawan, Yogyakarta: Gadjah Mada University Press.

Erwin, M. (2011). Hukum Lingkungan dalam Sistem Kebijaksanaan Pembangunan Lingkungan Hidup, Bandung: Refika Aditama.

Franky Butar-Butar. (2010). "Penegakan Hukum Lingkungan di Bidang Pertambangan", Jurnal Yuridika, Vol 25 No. 2, 189.

Husin, S. (2014). Penegakan Hukum Lingkungan Indonesia. Jakarta: Sinar Grafika.

Kartono. (2009). "Penegakan hukum Lingkungan Administratif dalam Undang-Undang Perlindungan dan Pengelolaan Lingkungan Hidup". Jurnal Dinamika Hukum, 9(3): 247-257.

Lioty, R.R. (2017). “Penanganan Illegal Tapping, Illegal Drilling dan Penyelewengan Bahan Bakar Minyak (BBM) Bersubsidi di Indonesia Tahun 2011-2015". Jurnal of International Relations, 3 (4): 96-105.

Mina, R. (2016). “Desentralisasi Perlindungan dan Pengelolaan Lingkungan Hidup Sebagai Alternatif Menyelesaiakan Permasalahan Lingkungan Hidup". Jurnal Arena Hukum, 9 (2): 154.

Priyanta, M. (2015). "Pembaharuan dan Harmonisasi Peraturan Perundang-Undangan Bidang Lingkungan dan Penataan Ruang Menuju Pembangunan Berkelanjutan". Hasanuddin Law Review, 1(3): 337-349.

Puluhulawa, F.U. (2011). “Pengawasan Sebagai Instrumen Penegakan Hukum pada Penglolaan Usaha Pertambangan Mineral dan Batu Bara". Jurnal Dinamika Hukum, 11(2): 306-315.

So Woong Kim. (2013). “Kebijakan Hukum Pidana Dalam Upaya Penegakan Hukum Lingkungan Hidup". Jurnal Dinamika Hukum. 13 (3): 415-427.

Subyakto, K. (2015). "Azas Ultimum Remidium Ataukah Azas Primum Remidium yang Dianut dalam Penegakan Hukum Pidana pada Tindak Pidana Lingkungan Hidup pada UU No. 32 Tahun 2009 tentang Perlindungan dan Pengelolaan Lingkungan Hidup". Jurnal Pembaharuan Hukum, 2(2): 2019-213.

Sununianti, V.V. (2018). "Labor and Sustainable Development in Traditional Oil Mining", IOP Conference Series: Earth and Environmental Science, Volume 145, conference 1: doi:10.1088/1755-1315/145/1/012105

Widowaty, Y. (2012). “Konsep Sustainable Develompment sebagai Bentuk Perlindungan terhadap Korban Tindak Pidana Lingkungan Hidup". Jurnal Media Hukum, 19 (2): 260-275. 